\title{
3. SEAFLOOR SPREADING IN THE MARIANA TROUGH: RESULTS OF LEG 60 DRILL SITE SELECTION SURVEYS 1
}

\author{
Patricia Fryer and Donald M. Hussong, Hawaii Institute of Geophysics, University of Hawaii, Honolulu, Hawaii
}

\begin{abstract}
A detailed geophysical and geological survey of the Mariana Trough, an actively extensional back-arc basin, was conducted in 1976 and 1977 to provide data for selection of drilling sites for DSDP Leg 60. These surveys revealed large-scale bathymetric trends, sediment distribution, crustal seismic veolocity structure, and earthquake activity that suggest the basin is opening around an axial spreading center tectonically similar to the slowly spreading Mid-Atlantic Ridge. There are, however, significant differences in the character of the trough, such as poorly defined magnetic anomalies, extreme bathymetric relief, and the frequent occurrence of low-magnitude earthquakes but absence of larger seismic events. Seafloor spreading in the Mariana Trough may be characteristic of the initial opening stages of any oceanic rift system, whether or not it is in a back-arc setting.
\end{abstract}

\section{INTRODUCTION}

Based on bathymetric trends and sediment distribution, Karig (1971) suggested that the Mariana Trough (Fig. 1) is an actively opening back-arc basin. The variable, and often quite high, heat flow subsequently observed (Anderson, 1975) in the basin supported this interpretation. Thus when the International Phase of Ocean Drilling (IPOD) planned an east-west transect of the Philippine plate at approximately $18^{\circ} \mathrm{N}$ latitude, the Mariana Trough was identified as an obvious target for the study of crustal genesis and the nature of seafloor spreading in a back-arc environment (see Mariana Trough-Background and Objectives, Uyeda and Hussong, this volume). The selection of drilling sites in the Mariana Trough was based largely on data collected during reconnaissance and detailed geophysical surveys and geological sampling conducted for IPOD by the Hawaii Institute of Geophysics (HIG) in 1976 and 1977. This chapter summarizes the results of those surveys.

Prior to the HIG surveys, although marine geological and geophysical data about the Mariana Trough were generally sparse, the center of the basin near the proposed $18^{\circ} \mathrm{N}$ transect had been intensively studied. Here, geophysical data and samples of seafloor sediment and crustal material had been collected by three Scripps Institution of Oceanography (SIO) cruises (SCAN, TASADAY, and INDOPAC). The Lamont-Doherty Geological Observatory (L-DGO) also had several existing ship tracks with geophysical profiles through this area. For the IPOD site selection, HIG surveyed the entire width of the basin near $18^{\circ} \mathrm{N}$ in 1976 (Fig. 2) and followed this effort in 1977 with more detailed surveying (Fig. 3) in those localities considered most appropriate to meeting the IPOD drilling objectives. That same year the HIG data were supplemented by multichannel seismic reflection data collected by Lamont-Doherty Geological Ob-

\footnotetext{
${ }^{1}$ Initial Reports of the Deep Sea Drilling Project, Volume 60.
}

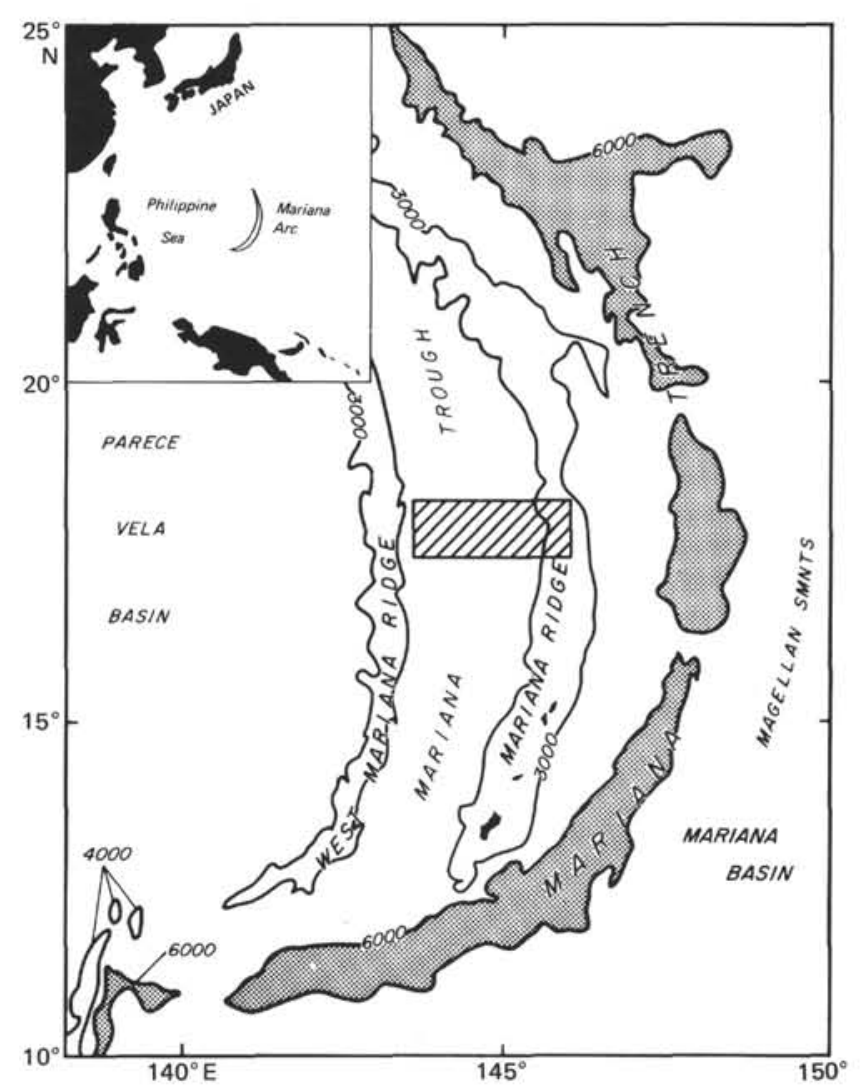

Figure 1. Location of the Mariana Trough, an extensional back-arc basin associated with the Mariana Island arc zone of lithospheric plate convergence. The shaded box encloses the area surveyed and described in this paper. Map modified from Karig (1971) and Ambos (1980).

servatory using the Conrad (Mrozowski et al., this volume).

All ship's navigation for these surveys is satellitecontrolled. On the Kana Keoki, the HIG vessel used to collect the bulk of the profiling data, the position between satellite fixes is interpolated and adjusted using 


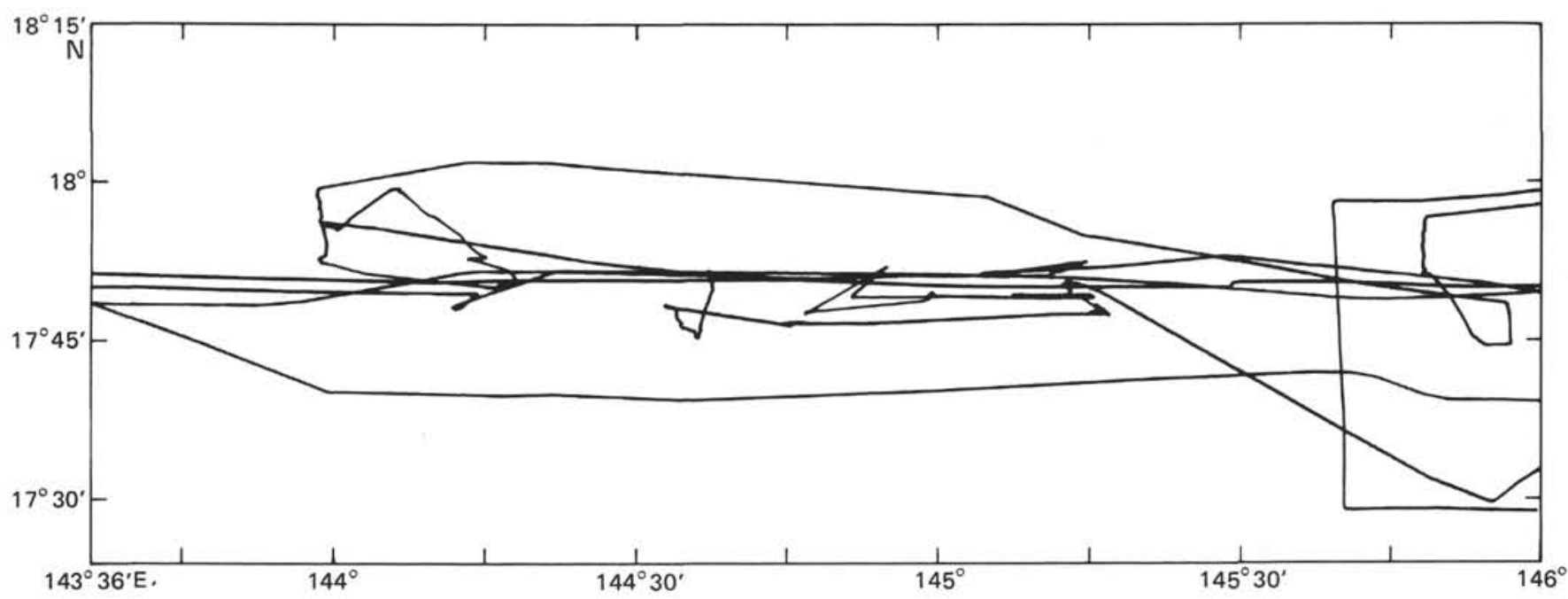

Figure 2. Tracks of the 1976 Hawaii Institute of Geophysics drillsite selection survey, R/V Kana Keoki cruise KK-76-01-03, Leg 2.

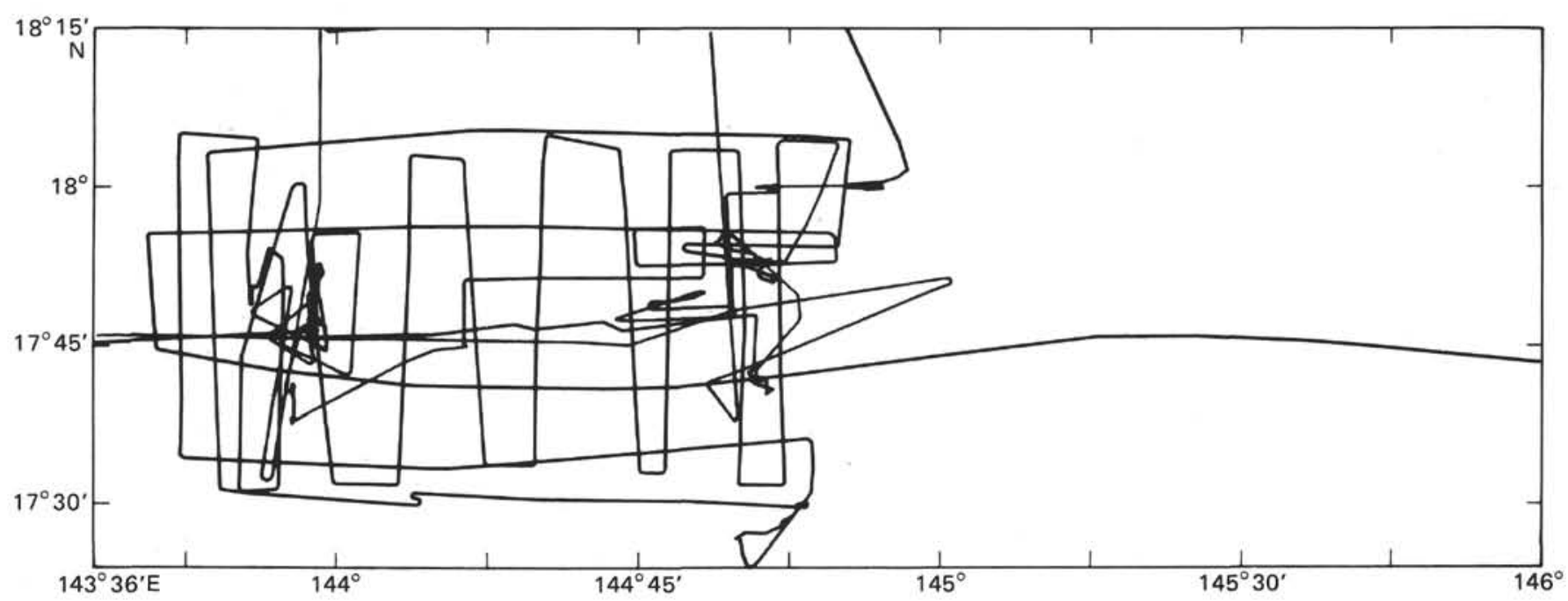

Figure 3. Tracks of the 1977 Hawaii Institute of Geophysics drillsite selection survey, R/V Kana Keoki cruise KK-77-03-17, Legs 3 and 4.

continuously recorded ship's heading and speed-throughwater (obtained from an electromagnetic sword).

\section{HIG DATA}

\section{Bathymetry}

A bathymetric map of the Mariana Trough, based primarily on $3.5-\mathrm{kHz}$ reflection data from the HIG, SIO, and L-DGO cruises is shown in Figure 4 and Plate 1 (back pocket, this volume). The bathymetry is corrected for variations in sound velocity in water using standard Matthew's Tables.

The seafloor in the Mariana Trough is characterized by very high relief and a roughly north-south trending system of irregular ridges and valleys. In the area surveyed near $18^{\circ} \mathrm{N}$, depths range from extremes of over 4800 meters to less than 2800 meters, although typical valley-to-ridge relief is more like 600 to 900 meters. Although the back-arc basin relief is more extreme, the general character of the sea bottom is similar to that found on slow-spreading mid-ocean ridges, such as the Mid-Atlantic Ridge.

A deep (4600-m) graben runs generally northwestsoutheast, approximately equidistant from the center of the active Mariana volcanic arc on the east and the remnant arc (West Mariana Ridge) on the west. The graben crosses $18^{\circ} \mathrm{N}$ at $144^{\circ} 48^{\prime} \mathrm{E}$. It is flanked by a series of narrow block-faulted ridges and troughs oriented parallel to the graben. The character of the graben and of the flanking ridges can be seen on east-west reflection seismic profiles (Fig. 5A and B) and Plate 2 (back pocket). The basement topography is roughly mirrored on the two sides of the apparent graben at the axis of back-arc spreading. Also, on both sides of the basin the individual ridges are generally asymmetric with the steeper flanks on the side nearest the axis of spreading, suggesting they are formed by block faulting with rotation away from the axial graben (Fig. 6A). North-south reflection profiles (Fig. 6B) show a series of much broader rises and deeps with considerably more gentle 


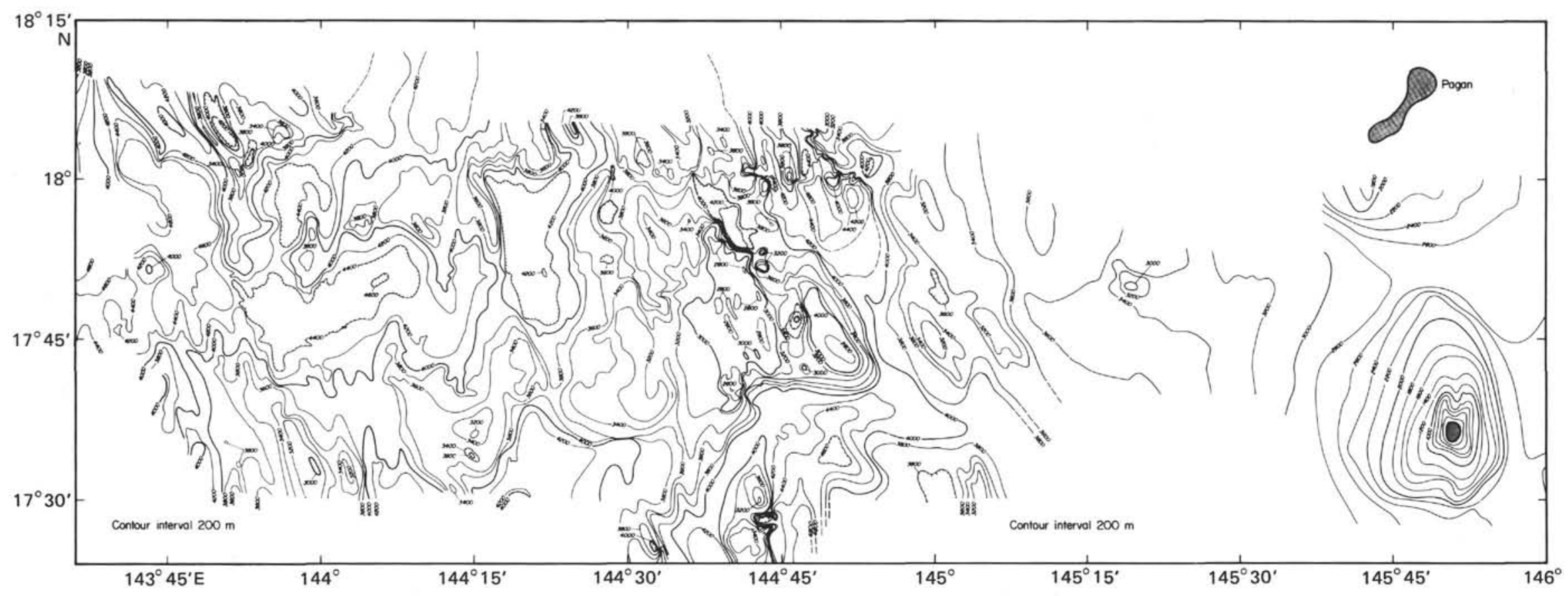

Figure 4. Bathymetry of the Mariana Trough. Data sources are the HIG cruises, Figures 2 and 3, supplemented by all available data from the Scripps Institution of Oceanography, the Deep Sea Drilling Project, and the Lamont-Doherty Geological Observatory. Contours in meters cor rected for velocity of sound in water using Matthew's Tables. 

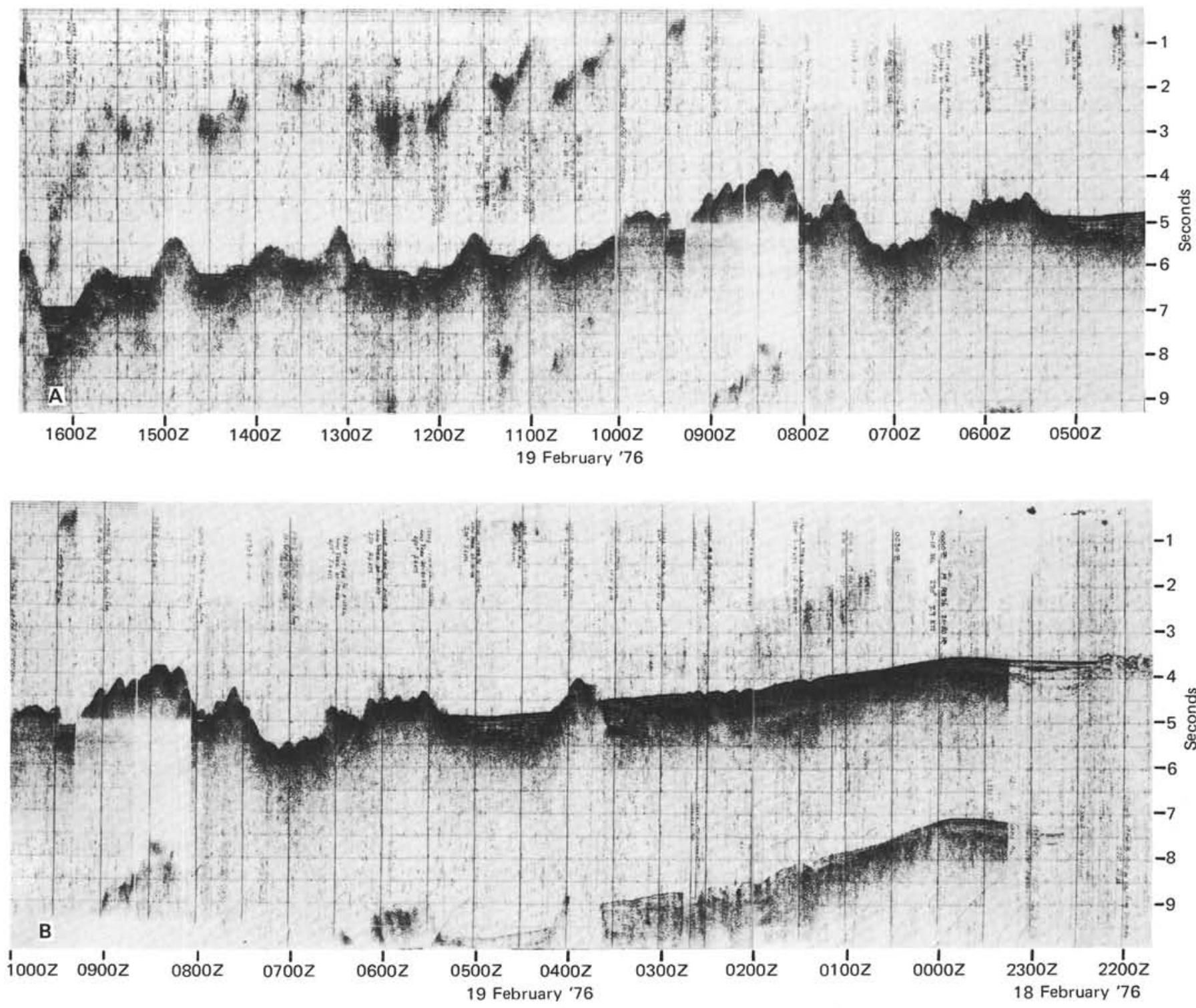

Figure 5. A. Single-channel receiver, airgun source, reflection seismic profile across the western half of the Mariana Trough at $17^{\circ} 50^{\prime} \mathrm{N}$ latitude. The ship's course was $270^{\circ} \mathrm{T}$. Data filtered $20-80 \mathrm{~Hz}$. B. Eastern continuation of reflection seismic profile in Figure $5 \mathrm{~A}$. The Mariana Trough basement is covered on this side by a wedge of thick volcaniclastic sediments coming from the presently active Mariana volcanic arc.

slopes, illustrating the persistent north-south fabric of the back-arc basin bathymetry. Since the ridges strike about $330^{\circ}$, their steep sides (facing the spreading center) are on the east in the east-west profile (Fig. 6A) and are on the north faces in the north-south profile (Fig. 6B).

The well-defined axial graben is not, however, an ubiquitous feature in the Mariana Trough. Inspection of reflection profiles to the north and to the south of the survey area shows that although the lineated bathymetric fabric continues, the central graben at other latitudes is less pronounced and is sometimes replaced by an axial bathymetric high.

South of $17^{\circ} 35^{\prime} \mathrm{N}$ in our surveyed area (Fig. 4), a major east-west-trending bathymetric feature coincides with a right lateral offset in the central graben. The most striking aspect of this east-west feature is a sediment-filled deep with water depths greater that 4000 meters. It is bounded on the north by an approximately 800-meter scarp. This scarp has a large-scale strike of approximately $255^{\circ}$, but on a scale of the order of 10 $\mathrm{km}$, it changes strike direction over short intervals from nearly $180^{\circ}$ to $270^{\circ}$. The feature is probably an unstable transform fault that repeatedly changes its trend in response to small-plate irregularities in spreading direction. These confused spreading geometries are characteristic of the Mariana Trough, perhaps because in their initial opening stages small basins lack a stable single pole of spreading.

Based on the bathymetry and sediment trends, we suggest that a generalized ridge-transform-ridge structure occurs in the Mariana Trough (Fig. 7).

A recent deployment of ocean bottom seismometers in this part of the Mariana Trough recorded a large number of low-energy (magnitude less than 3.5) earthquakes with an epicenter pattern consistent with the 


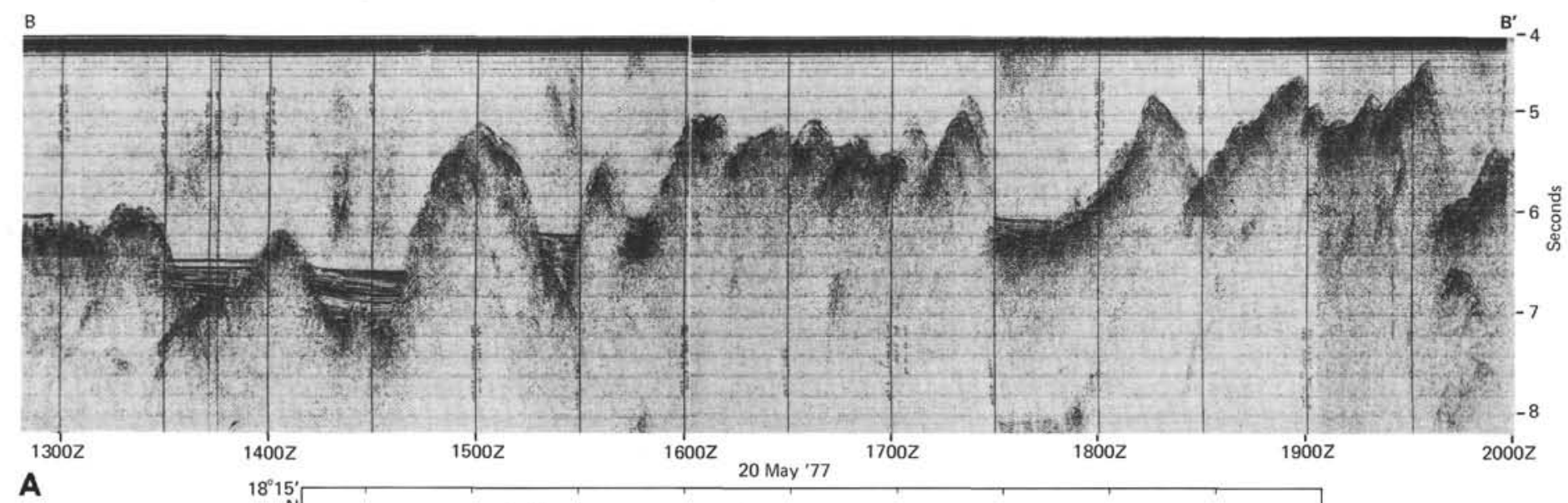

A

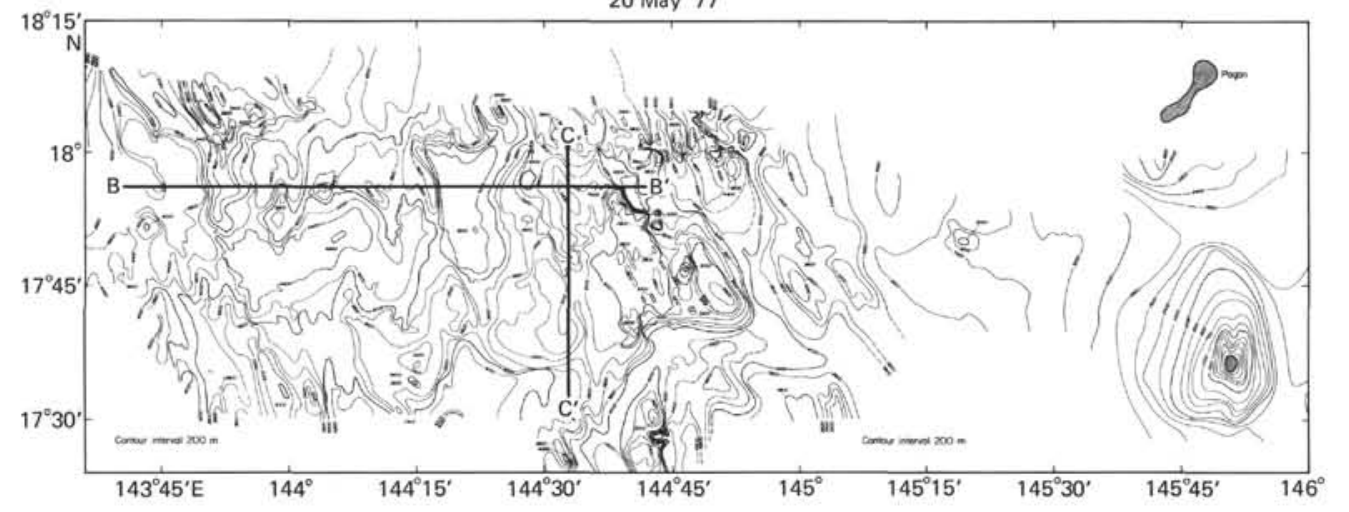

B

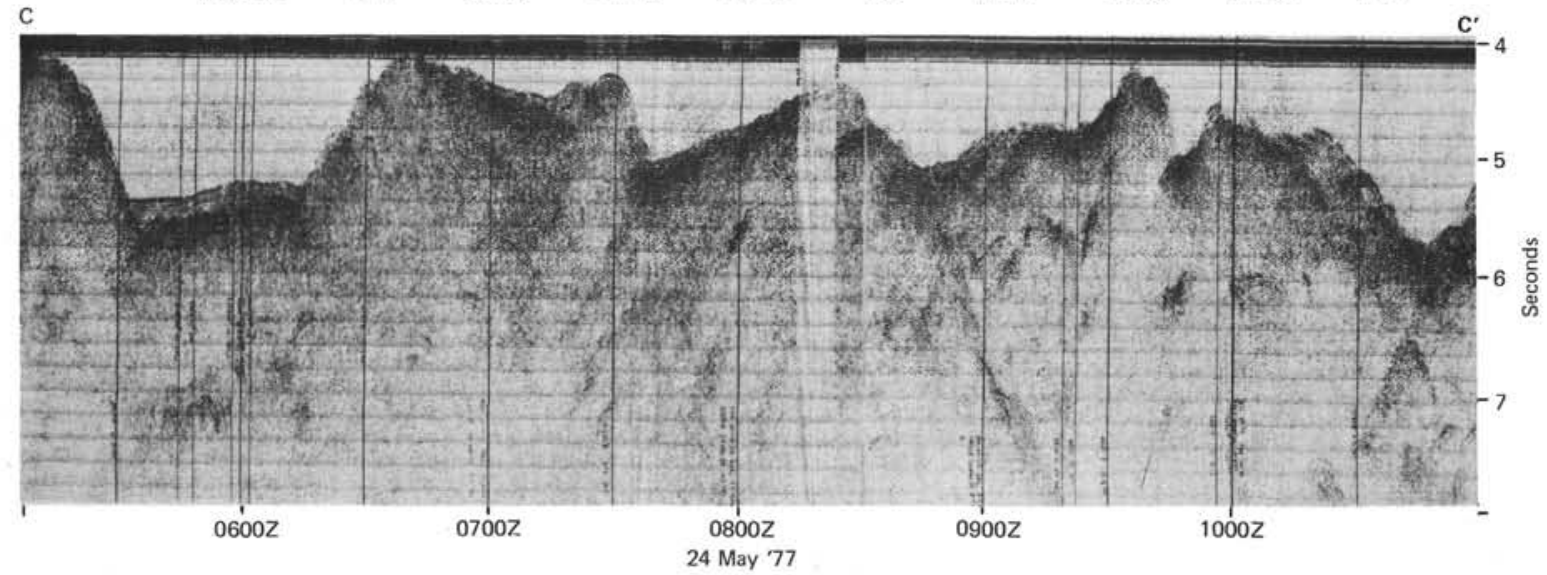

Figure 6. A. Single-channel receiver, airgun source, reflection seismic profile in the western side of the Mariana Trough. Data filtered $40-250 \mathrm{~Hz}$. This profile, made on a course of $90^{\circ} \mathrm{T}$, illustrates the apparent rotation of the block-faulted ridges away from the axis of spreading so that the steeper scarps on the ridges always face east. B. A north-south line obtained with the same seismic profiling setup as in A. The longer wavelength of the bathymetric 


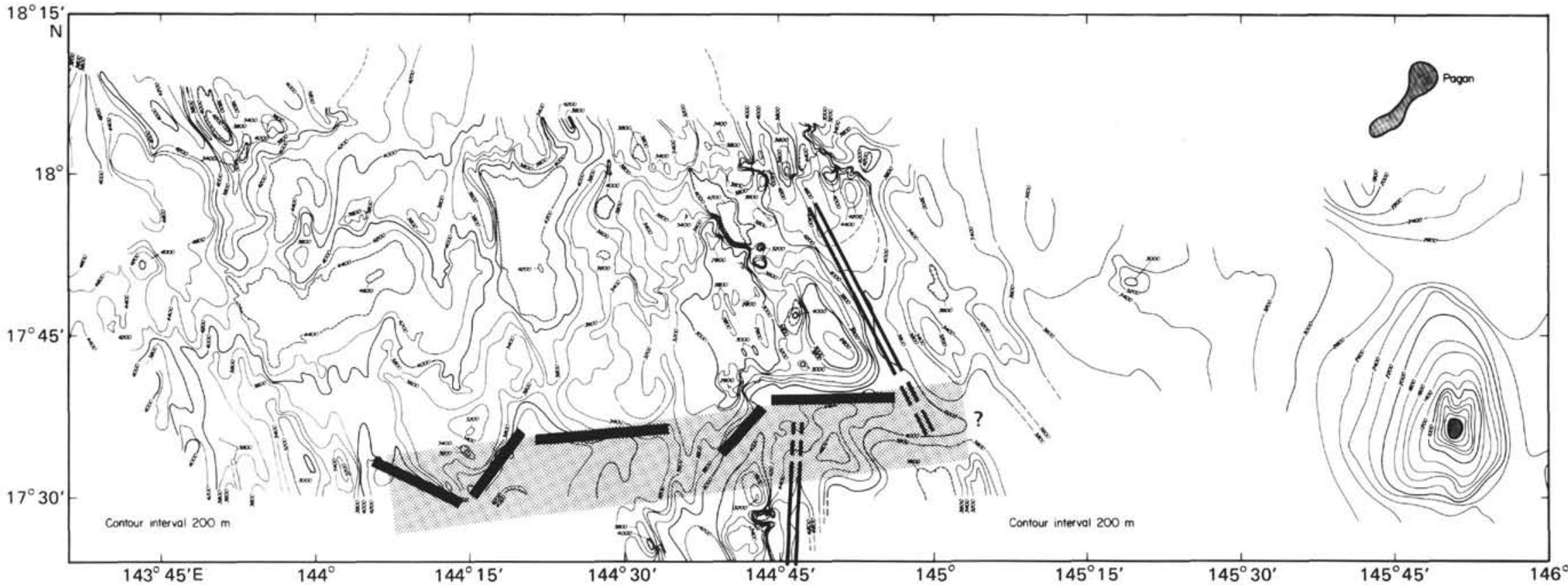

Figure 7. Tectonic interpretation of Mariana Trough bathymetric and geophysical trends. Spreading occurs from a discontinuous axial graben striking approximately $330^{\circ} \mathrm{T}$ in the upper part of the study area and from a north-south rift south of $17^{\circ} 35^{\prime} \mathrm{N}$. The intervening fracture zone is bounded on the north by scarps that strike in directions sometimes orthogonal to the northern spreading center and at other times orthogonal to the more southerly spreading center. The entire shaded area represents the deep, sediment-filled, seismically active area that is the irregular trace of this apparent constantly reorienting transform fault. 
spreading ridge-transform fault structure deduced from the bathymetry (Hussong and Sinton, 1979). No shallow earthquakes with magnitudes $>3.5$ have been reported in the trough.

\section{Sediment Distribution}

Sediments in the Mariana Trough are sparse in the center and become progressively thicker toward the margins. A large wedge of pyroclastic debris extends westward from the Mariana volcanic islands and covers the eastern side of the Mariana Trough nearly to the axial region (Fig. 5B). Toward the western side of the back-arc basin the sediment cover shows a general thickening, and there is an increase in size and frequency of sediment ponds. Most of these ponds show evidence of tectonic displacement (for example, see Fig. 5A). In some ponds, faulting has destroyed the continuity of the stratigraphy; in many there are angular unconformities at depth. The sediment pond graben observed in the profile in Figure 5A (labeled " $A$ "), for instance, is in an enclosed basin that is unlikely to be disturbed by bottom currents. Since the sediments in these ponds are predominantly turbidites, the abrupt nature of the graben suggests that it was formed very recently and at a position over $75 \mathrm{~km}$ from the spreading axis.

Although the cause of some of the strong sub-bottom reflectors in the Mariana Trough sediment ponds is unknown, we recovered widespread pumice in the area during dredging (see later section on Rock Dredges), encouraging us to speculate that the deep reflectors may be buried layers of pumice.

\section{Magnetics}

The residual total magnetic intensity field, corrected for IGRF (International Geomagnetic Reference Field) using the 1965 parameters, is included in the charts presented in Plate 1 in the back pocket of this volume. As noted by Karig (1971), it is very difficult to correlate magnetic anomalies between profiles in the Mariana Trough-probably because of the combination of low latitude, rough bathymetry, and small-scale changes in the geometry of crustal spreading. It required considerable smoothing of crossline errors to produce the magnetic contour map on Plate 1, and concurrent attempts at correlating anomalies among profiles to identify a spreading-induced magnetic anomaly stripe were not conclusive. It seems that the small-scale spreading irregularities evident in the erratic strikes of the scarps on the $17^{\circ} 35^{\prime} \mathrm{n}$ fracture zone are so great that no identifiable magnetic anomaly trends are observed, despite the dense line spacing obtained during the survey.

Fortunately, other attempts to correlate magnetic anomalies have had some success. Hussong and Fryer (1980) studied profiles from a variety of other academic and military research cruises in the Mariana Trough just north of $18^{\circ} \mathrm{N}$ latitude and calculated a spreading rate of approximately $1.65 \mathrm{~cm} / \mathrm{y}$. $(3.30 \mathrm{~cm} / \mathrm{y}$. total basin extension). Bibee et al. (1980) were also able to correlate several profiles near $18^{\circ} \mathrm{N}$ and calculated a spreading rate of approximately $1.5 \mathrm{~cm} / \mathrm{y}$. $(3 \mathrm{~cm} / \mathrm{y}$. total extension) within $50 \mathrm{~km}$ (therefore $3 \mathrm{~m} . \mathrm{y}$.) of the spreading axis. These slow spreading rates are consistent with the ages of basal sediments subsequently cored at Sites 453 , 454 , and 456 (see site chapters, this volume).

\section{Gravity}

Gravity data were collected using a La Coste and Romberg S-33 gravimeter. In general the FAA field (included on Plate 1, back pocket of this volume) follows bathymetric trends in the survey area. Interpretation of these data by Sager (1980) is consistent with a crustal thickness of $5 \mathrm{~km}$ across the trough with some thinning near the axis of spreading. In general, Sager's interpretation requires that the back-arc crust and upper mantle densities be lower that those observed in the lithosphere beneath ocean basins.

\section{Seismic Refraction Studies}

Locations of sonobuoy and ocean bottom seismometer (OBS) deployments, and the shotlines along which refraction data were collected, are shown in Figure 8. Velocity determinations by LaTraille and Hussong (1980), using sonobuoy data from the 1976 HIG cruise, are presented in Table 1. Since these interpretations are based solely on east-west shotlines, which are perpendicular to the dominant bathymetric grain, velocity determinations and interpretations are hampered by complexity of the crustal structure. In addition, the quality of seismic arrivals on these stations was often poor, making development of structural models even more difficult. Moho velocities were detected only in the western part of the trough (stations 2, 3, 4, and 5). The average crustal thickness beneath these stations is $5 \mathrm{~km}$, with some apparent thinning toward the axial region. The velocity and thickness determinations of Layer $2 \mathrm{~A}$ are similar to those at the Mid-Atlantic Ridge (Houtz and Ewing, 1976) but are low by comparison with those at the East Pacific Rise. The velocity determinations of Layers $2 \mathrm{~B}$ and 3 are also similar to those of the MidAtlantic Ridge.

Structural models based on the 1977 OBS data were obtained by the heterogeneous ray tracing method (Ambos, 1980), allowing for lateral inhomogeneity in the velocities of the crustal layers. These interpretations are summarized in Table 2. Some of the problems encountered during interpretation of the sonobuoy data were alleviated in the OBS interpretation by running two shotlines north-south, parallel to the dominant strike of the bathymetric grain, and an additional line east-west across strike (Fig. 8). The easternmost of the two northsouth lines is located close to the axial graben, on very recently generated crust. The other is some $80 \mathrm{~km}$ to the west, on 5 to $6 \mathrm{~m} . \mathrm{y}$. old crust. Since the direction of spreading is approximately east-west, these two shotlines were located close to isochrons. No mantle arrivals were observed, although the $7.7 \mathrm{~km} / \mathrm{s}$ velocity could be classified as low-velocity mantle. Ambos (1980) also compared here Mariana Trough velocity structure to that reported on other mid-ocean spreading centers and concludes that the back-arc basin crustal velocity structure is quite similar to that observed on slow-spreading mid-ocean ridges. 


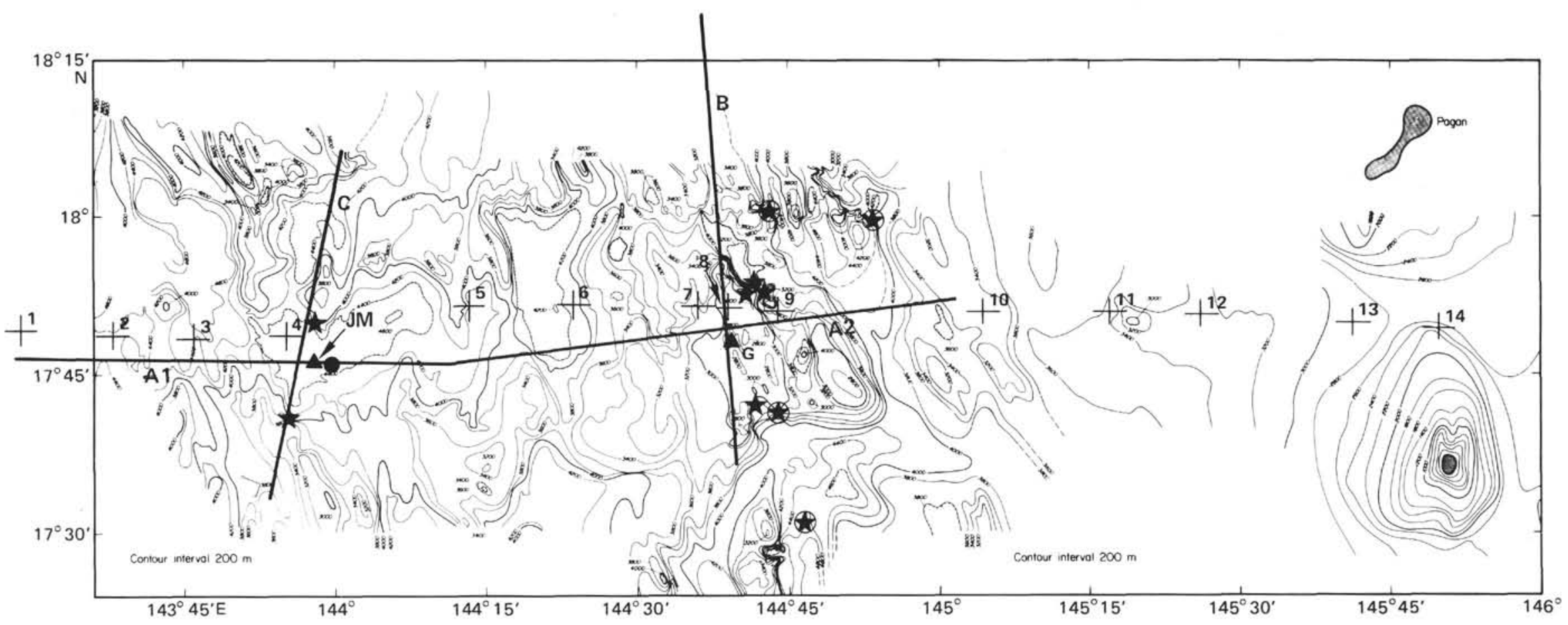

Figure 8. Location map of sonobuoy stations (crosses); ocean bottom seismometer stations (triangles); explosion shotlines, dredge hauls (stars); positions where fresh basalt was recovered (circled stars); and piston core (solid circle) in the survey area. 
Table 1. Results of 1976 seismic refraction studies (sonobuoy data).

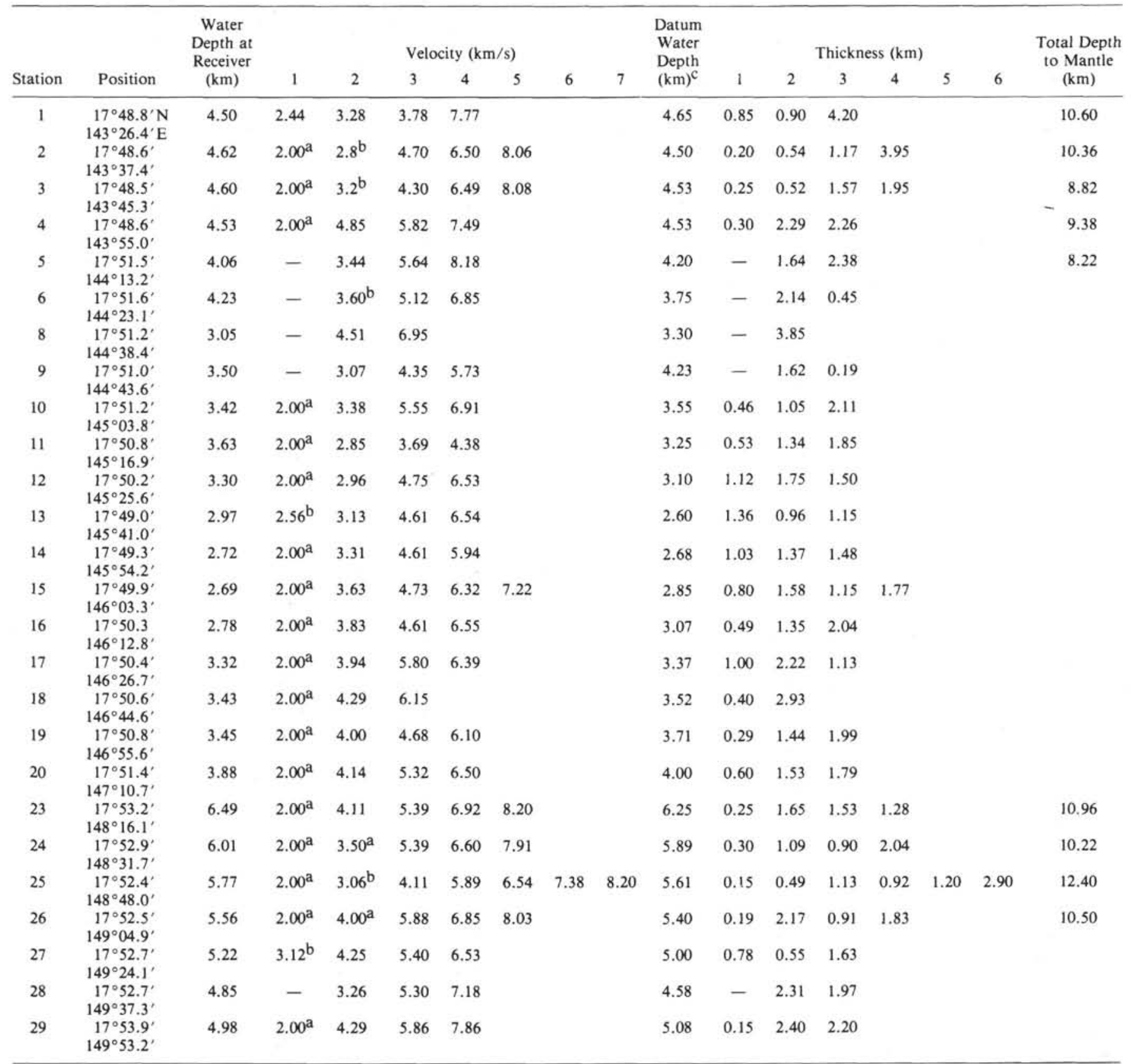

Note: From LaTraille and Hussong (1980).

a Assumed velocity.

b Average velocity - a gradient, not a discrete layer.

c Averaged along the datum for each station.

Table 2. Results of 1977 seismic refraction data (OBS data).

\begin{tabular}{|c|c|c|c|c|c|c|c|c|c|c|}
\hline \multirow[b]{2}{*}{ OBS } & \multirow{2}{*}{$\begin{array}{l}\text { Instrument } \\
\text { Position }\end{array}$} & \multirow{2}{*}{$\begin{array}{l}\text { Water } \\
\text { Depth } \\
(\mathrm{km})\end{array}$} & \multirow[b]{2}{*}{ Line } & \multicolumn{4}{|c|}{ Velocity $(\mathrm{km} / \mathrm{s})$} & \multicolumn{3}{|c|}{ Thickness $(\mathrm{km})$} \\
\hline & & & & 2 & 3 & 4 & 5 & 2 & 3 & 4 \\
\hline Jan Mayen & $\begin{array}{r}17^{\circ} 46.5^{\prime} \mathrm{N} \\
144^{\circ} 02.0^{\prime} \mathrm{E}\end{array}$ & 4.5 & C & 3.5 & 5.3 & 6.7 & 7.7 & 1.8 & 1.5 & 1.8 \\
\hline Gifu & $\begin{array}{r}17^{\circ} 49.5^{\prime} \mathrm{N} \\
144^{\circ} 39.0^{\prime} \mathrm{E}\end{array}$ & 2.8 & B & 3.5 & 6.4 & \pm 0.34 & 7.7 & 1.6 & & 2.3 \\
\hline Jan Mayen & $\begin{array}{r}17^{\circ} 46.5^{\prime} \mathrm{N} \\
144^{\circ} 02.0^{\prime} \mathrm{E}\end{array}$ & 4.5 & A1 & 3.5 & 5.3 & 6.7 & 7.7 & 1.4 & 1.3 & 1.4 \\
\hline Gifu & $\begin{array}{r}17^{\circ} 49.5^{\prime} \mathrm{N} \\
144^{\circ} 39.0^{\prime} \mathrm{E}\end{array}$ & 2.8 & A2 & 3.3 & 6.4 & \pm 0.34 & 7.7 & 1.9 & & .0 \\
\hline
\end{tabular}

Note: From Ambos (1980).

\section{Seismicity}

During the four days the OBS units were deployed in 1977, a number of low-magnitude seismic events were recorded. Although exact locations cannot be determined, the frequency of these events was greatest (approximately 35 per day) at the units along the eastern end of the line. Recent seismic studies in the southeastern part of the survey area (Hussong and Sinton, 1979) show patterns of earthquake epicenters consistent with a ridge-transform fault type of extension. 


\section{Sediment Cores}

Two free-fall cores and two piston cores were collected from the survey area; their locations are shown in Figure 8. The easternmost of the cores recovered volcanic ash and brown clay with Quaternary foraminifers throughout. A piston core from the suspected back-arc spreading axis yielded clay and ash with macromanganese nodules. The remaining two cores were from large sediment ponds in the western part of the Trough. Both yielded primarily vitric ash. The westernmost of the two cores also contains layers of pumice and silty vitric clay. The ages of these three cores are also Quaternary.

\section{Rock Dredges}

The locations of dredge stations are also shown in Figure 8 and a summary of dredge results listed in Table 3 . Most of the stations were concentrated in the center of the trough, near the suggested spreading axis. A large amount of very fresh pillow basalt and some coarsergrained mafic material was collected there. Some of the rocks were highly altered by hydrothermal effects. The two sites dredged from the scarps surrounding the large western pond yielded manganese nodules and pumice. The pumice is light gray and contains abundant hornblende phenocrysts. Some of the pieces of pumice have a thick manganese encrustation. The same sort of pumice, and some slabs of manganese, were recovered from the southern boundary of the large seamount near the axial region of the trough.

The pillow basalts collected near the axial region bear many characteristics of mid-ocean ridge basalt (MORB), but there are significant differences in certain major and trace element compositions (Fryer et al., this volume;
Garcia et al., 1979). Concentrations of $\mathrm{Al}_{2} \mathrm{O}_{3}$ and volatiles are higher and total iron and $\mathrm{TiO}_{2}$ are lower than those of MORB at a given $\mathrm{MgO}$ concentration. Rare earth abundances cluster near the upper limit for MORB and the patterns are essentially flat compared with chondritic abundances $(\mathrm{Ce} / \mathrm{Sm}=0.8-1.1)$. Certain incompatible elements ( $\mathrm{Li}, \mathrm{K}, \mathrm{Rb}, \mathrm{Sr}, \mathrm{Ba})$ are more abundant in some of the Mariana Trough basalts than in MORB. The differences in composition between the basin lavas and ridge basalts indicate a difference in source material. Part of the reason for these differences might be the peculiar environment of the active back-arc basin, in particular its location above the subducted oceanic lithospheric plate.

\section{SUMMARY}

Results of the site selection surveys made a considerable contribution to understanding the style of spreading in the Mariana Trough. Spreading seems to be approximately symmetrical from a central rift that bears morphologic similarity to other slow-spreading ridges. Refraction data indicate a velocity structure similar to the slow-spreading Mid-Atlantic Ridge. Seismic activity in the spreading region also implies normal mid-ocean ridge tectonics. Finally, the overall petrologic and compositional characteristics of the lavas dredged from the spreading center are similar to MORB.

Although the Mariana Trough bears much in common with normal slow-spreading mid-ocean ridges, there are also striking differences. Poorly defined magnetic lineation patterns are very difficult to correlate, but where identifiable they are consistent with symmetric ridge-transform fault extension. The spreading rate (approximately $1.65 \mathrm{~cm} / \mathrm{y}$.), however, is unusually low. In

Table 3. Results of rock dredges.

\begin{tabular}{|c|c|c|c|c|c|c|c|}
\hline $\begin{array}{l}\text { Dredge } \\
\text { No. }\end{array}$ & Latitude $\mathrm{N}$ & Longitude $\mathrm{E}$ & $\begin{array}{l}\text { Water } \\
\text { Depth } \\
\text { (m) }\end{array}$ & No. Bags & $\begin{array}{l}\text { No. Loose } \\
\text { Boulders }\end{array}$ & Lithology & General Location \\
\hline M 01 & $17^{\circ} 53^{\prime}$ & $144^{\circ} 41.7^{\circ}$ & 3200 & 2 & & $\begin{array}{l}\text { Altered basalt pillow } \\
\text { fragments and manganese } \\
\text { nodules }\end{array}$ & $\begin{array}{l}\text { North slope of axial high } \\
\text { seamount, lower part of } \\
\text { slope }\end{array}$ \\
\hline M 02 & & & & & & Dredge empty & \\
\hline M 03 & $17^{\circ} 23.3^{\circ}$ & $144^{\circ} 42.9^{\prime}$ & $\begin{array}{l}3200- \\
4000\end{array}$ & 17 & 4 & $\begin{array}{l}\text { Fresh to altered basalt } \\
\text { pillow fragments }\end{array}$ & $\begin{array}{l}\text { Western slope of axial } \\
\text { valley in talus pile at } \\
\text { base of slope }\end{array}$ \\
\hline M 04 & & & & & & Lost dredge & \\
\hline MOS & $17^{\circ} 52.8^{\circ}$ & $144^{\circ} 40.1^{\circ}$ & 3100 & & 1 & One manganese nodule & $\begin{array}{l}\text { Northern scarp of axial } \\
\text { high seamount }\end{array}$ \\
\hline M 06 & $17^{\circ} 53.7^{\circ}$ & $144^{\circ} 41.7^{\prime}$ & 3400 & 1 & & $\begin{array}{l}\text { Altered basalt fragments } \\
\text { and some manganese } \\
\text { nodules }\end{array}$ & $\begin{array}{l}\text { Northern scarp of axial } \\
\text { high seamount }\end{array}$ \\
\hline M 07 & $17^{\circ} 41.0^{\prime}$ & $144^{\circ} 43.1^{\prime}$ & 3700 & 5 & 4 & $\begin{array}{l}\text { Basalt pillow fragments } \\
\text { slightly to heavily } \\
\text { altered }\end{array}$ & $\begin{array}{l}\text { Southern slope of axial } \\
\text { high seamount }\end{array}$ \\
\hline M 08 & $17^{\circ} 42.6^{\prime}$ & $144^{\circ} 41.4^{\prime}$ & 3000 & 1 & & $\begin{array}{l}\text { Manganese nodules and } \\
\text { pumice fragments }\end{array}$ & $\begin{array}{l}\text { Upper part of southern } \\
\text { boundary of axial high } \\
\text { seamount }\end{array}$ \\
\hline M 09 & $17^{\circ} 49.6^{\prime}$ & $143^{\circ} 59.0^{\circ}$ & 4200 & 5 & & $\begin{array}{l}\text { Manganese nodules and } \\
\text { pumice fragments }\end{array}$ & $\begin{array}{l}\text { Northern boundary of } \\
\text { sediment pond SP4c }\end{array}$ \\
\hline M 10 & $18^{\circ} 19.2^{\prime}$ & $144^{\circ} 26.2^{\prime}$ & 3600 & 2 & & Manganese nodules & $\begin{array}{l}\text { North of survey area } \\
\text { on steep slope of } \\
\text { fault block }\end{array}$ \\
\hline M 11 & $17^{\circ} 41.0^{\circ}$ & $143^{\circ} 56.0^{\prime}$ & 4200 & 5 & & $\begin{array}{l}\text { Pumice and pumice with } \\
\text { manganese armor }\end{array}$ & $\begin{array}{l}\text { Southern boundary of } \\
\text { sediment pond SP4c }\end{array}$ \\
\hline M 12 & & & & & & Dredge empty & \\
\hline$M 13$ & $18^{\circ} 00.3^{\prime}$ & $144^{\circ} 43.4^{\prime}$ & 3900 & 6 & 5 & $\begin{array}{l}\text { Fresh pillow basalt } \\
\text { fragments }\end{array}$ & $\begin{array}{l}\text { Western scarp boundary } \\
\text { axial valley northern } \\
\text { part of survey area }\end{array}$ \\
\hline M 14 & $18^{\circ} 00.4^{\prime}$ & $144^{\circ}=53.3$ & 4400 & 8 & 7 & $\begin{array}{l}\text { Fresh to slight altered } \\
\text { pillow fragments. } \\
\text { conglomerate and some } \\
\text { sediment partly lithified }\end{array}$ & $\begin{array}{l}\text { Base of eastern scarp } \\
\text { bounding axial valley } \\
\text { in talus }\end{array}$ \\
\hline
\end{tabular}


some places the axial rift graben of the Mariana Trough looks similar to that of the Mid-Atlantic Ridge, but it is deeper $(4600 \mathrm{~m})$ than the graben of a normal mid-ocean ridge. The degree and complexity of faulting in the survey area are also greater than in most ridge provinces. Based on seismic and gravity data, upper mantle velocities and densities are low beneath the Mariana Trough. Although the earthquake epicenter patterns in the trough are similar to those of normal ridge-transform fault systems, the magnitude of these events is unusually low $(<3.5)$. Finally, although the composition of the basalts dredged in the trough are generally similar to MORB, consistent differences in volatile content and trace element composition, as well as subtle differences in major element composition, occur.

It may be that beyond its affinities with such a present-day feature as the Mid-Atlantic Ridge, the Mariana Trough back-arc basin should be considered for its geological and geophysical similarities to typical slowspreading mid-ocean ridges during initial stages of rifting. The composition of the basalts generated during crustal extension in this back-arc basin may also have been influenced by the nearby subducted oceanic lithospheric plate.

\section{ACKNOWLEDGMENTS}

We thank the scientific and ship's crew of the Kana Keoki for their dedication toward collection of these data. We are also indebted to
Larry Wipperman and Steve Dang for their assistance in reducing and contouring the data.

This work was funded by the National Science Foundation under the IPOD program of the Deep Sea Drilling Project, subcontracts CUHAWAII 25903 (1976) and CU-HAWAII 25906 (1977). This paper is Hawaii Institute of Geophysics Contribution 1143.

\section{REFERENCES}

Ambos, E. L., 1980. Crustal structure across the Mariana Island Arc. The Tectonic and Geologic Evolution of Southeast Asian Seas and Islands, Geophysical Monograph Series No. 22: Washington (American Geophysical Union).

Anderson, R. N., 1975. Heat flow in the Mariana marginal basin. $J$. Geophys. Res., 80:4043-4048.

Bibee, L. D., Shor, G. G., and Lu, R. S., 1980. Inter-arc spreading in the Mariana Trough. Mar. Geol., 35:183-197.

Garcia, M. O., Liu, N. W. K., and Muenow, D. W., 1979. Volatiles in submarine volcanic rocks from the Mariana Island Arc and Trough. Geochim. Cosmochim. Acta, (no. 3):305-312.

Houtz, R., and Ewing, J., 1976. Upper crustal structure as a function of plate age. J. Geophys. Res., 81:2490-2498.

Hussong, D. M., and Fryer, P., 1980. Tectonic evolution of the marginal basins behind the Mariana Arc. Geol. Soc. Am. Cordilleran Section Mtg.: Corvallis, Oregon. (Abstract)

Hussong, D. M., and Sinton, J. B., 1979. Low level seismicity in the Marianas Trough. EOS, 60(46):877. (Abstract)

Karig, D. E., 1971. Origin and development of marginal basins in the western Pacific. J. Geophys. Res., 76:2542-2561.

LaTraille, S. L., and Hussong, D. M., 1980. Crustal structure across the Mariana Island Arc. The Tectonic and Geologic Evolution of Southeast Asian Seas and Islands, Geophysical Monograph Series No. 22: Washington (American Geophysical Union).

Sager, W., 1980. Structure of the Mariana Arc referred from seismic gravity data. J. Geophys. Res., 85:5382-5388. 